TITLE:

\title{
Associational effects and the maintenance of polymorphism in plant defense against herbivores: review and evidence
}

\author{
AUTHOR(S): \\ Sato, Yasuhiro
}

\section{CITATION:}

Sato, Yasuhiro. Associational effects and the maintenance of polymorphism in plant defense against herbivores: review and evidence. Plant Species Biology 2018, 33(2): 91 108

\section{ISSUE DATE:}

2018-04

URL:

http://hdl.handle.net/2433/234646

\section{RIGHT:}

This is the peer reviewed version of the following article: Sato, Y. (2018), Associational effects and the maintenance of polymorphism in plant defense against herbivores: review and evidence. Plant Species Biology, 33: 91-108, which has been published in final form at https://doi.org/10.1111/1442-1984.12201. This article may be used for non-commercial purposes in accordance with Wiley Terms and Conditions for Use of Self-Archived Versions.; The full-text file will be made open to the public on 22 February 2019 in accordance with publisher's 'Terms and Conditions for Self-Archiving'. この論文は出版社版でありません。引用の際には出版社版をご確認ご利用ください。; This is not the published version. Please cite only the published version. 
1 Associational effects and the maintenance of polymorphism in plant defense against herbivores: review and evidence

3

4

Yasuhiro Sato ${ }^{1,2}$

5

$6 \quad{ }^{1}$ Center for Ecological Research, Kyoto University, Hirano 2-509-3, Otsu, Shiga

7 520-2113, Japan

$8{ }^{2}$ Department of Plant Life Sciences, Faculty of Agriculture, Ryukoku University,

9 Yokotani 1-5, Seta Oe-cho, Otsu, Shiga 520-2194, Japan

10 Phone: +81-77-599-5660; Fax: +81-77-599-5656

11 E-mail: $\underline{\text { sato.yasuhiro.36c@kyoto-u.jp }}$

12

13

14

15

16

17

18

19

20

21

22

23 


\section{Abstract}

26 Many plant species have evolved defense traits against herbivores. Associational effects

27 (AE) refer to a kind of apparent interaction where the herbivory risk to a focal plant

28 species depends on the composition of other plant species in a neighborhood. Despite

29 ample evidence for AE between different plant species, this point of view has rarely

30 been applied to polymorphism in defense traits within a plant species. The purpose of

31 this review is to highlight an overlooked role of conspecific $\mathrm{AE}$ in maintaining

32 polymorphism in antiherbivore defense. First, I present a general review of AE between

33 plant species and its role in the coexistence of plant species. This viewpoint of AE can

34 be applied to genetic polymorphism within a plant species, as it causes frequency- and

35 density-dependent herbivory between multiple plant types. Second, I introduce a case

36 study of conspecific AE in the trichome-producing (hairy) and glabrous plants of

37 Arabidopsis halleri subsp. gemmifera. Laboratory and semi-field experiment illustrated

38 that AE against the brassica leaf beetle Phaedon brassicae mediate a minority advantage

39 in defense and fitness between hairy and glabrous plants. Combined with a statistical

40 modeling approach, field observation revealed that conspecific AE can maintain the

41 trichome dimorphism via negative frequency-dependent selection in a plant population.

42 Finally, I discuss spatial and temporal scales at which AE contribute to shaping genetic

43 variation in antiherbivore defense in a plant metapopulation. Based on the review and

44 evidence, I suggest that AE play a key role in the maintenance of genetic variation

45 within a plant species.

47 Keywords: Frequency-dependent selection, Genetic variation, Herbivory, Neighbor

48 effects, Plant defense 


\section{Background}

50 Many plant species have evolved defensive traits, such as spines and toxins, against

51 herbivores (Schoonhoven et al. 2005). Natural plant populations exhibit genetic

52 variation in regard to chemical (Hughes 1991; van Dam et al. 1999; Chan et al. 2010)

53 and morphological defenses (Kivimäki et al. 2007; Wise et al. 2009). It is well known

54 that these defense traits are costly for plant growth and/or reproduction (e.g., Mauricio

55 1998; Elle et al. 1999; Züst et al. 2011). The theory of plant defense assumes that the

56 defense-growth tradeoff favors an optimal balance between the cost and benefit of

57 defense (Simms 1992), extinguishing variation in defense levels. Thus, it is difficult for

58 natural selection to maintain genetic variation in antiherbivore defense traits unless a

59 stabilizing mechanism occurs.

Plant defense theory has focused on how individual plants allocate their

resource to defensive traits (e.g., Rhoades 1979; Simms 1992; Stamp 2003). However,

the defensive effects of a particular trait depend not only on a plant's own trait but also

on the composition of the other plant types in a neighborhood (Agrawal et al. 2006;

64 Barbosa et al. 2009; Underwood et al. 2014). These phenomena are called associational

65 effects (AEs: also known as neighbor effects), which occur when "consumer effects on

66 individuals of one resource organism type, at a given density of that type, are a function

67 of the neighborhood composition of other resource types at particular spatial scales"

68 (Underwood et al. 2014). An increasing number of studies have shown the importance

69 of AE in maintaining plant species diversity (e.g., Hay 1986; Callaway et al. 2005;

70 Stastny \& Agrawal 2014), but this point of view has rarely been tested in the

71 evolutionary ecology of antiherbivore defenses. 
73 critical role of conspecific $\mathrm{AE}$ in the maintenance of genetic variation in antiherbivore

74 defense traits. This paper consists of three chapters, in which I first outline the

75 ecological roles of AE in maintaining plant species diversity. Second, I introduce a case study on Arabidopsis trichomes to expand the concept of AE to polymorphism in defense within a plant species. Finally, I discuss how AE contributes to intraspecific variation in plant defense at larger spatial and temporal scales. Based on the review and evidence, the present paper suggests that AE plays a key role in maintaining not only species diversity but also genetic variation in antiherbivore defense.

\section{1-1. Examples of AE in plant-herbivore interaction}

The phenomena of associational resistance or susceptibility have been reported across agricultural (Tahvanainen \& Root 1972; Risch 1981; Le Guigo et al. 2012), forest (White \& Whitham 2000; Sholes 2008; Castagneyrol et al. 2013), grassland (Agrawal 2004; Courant \& Fortin 2010; Hahn \& Orrock 2016), semi-arid (González-Teuber \& Gianoli 2007), wetland (Rand 2003; Hughes 2012), and aquatic (Hay 1986; Wahl \& Hay 1995) ecosystems (see Appendix for selected examples). Two major patterns have been reported for AE between plant species: Associational resistance or susceptibility refer, respectively, to a situation where a focal plant species is less or more damaged in the presence of another plant species. Undefended plants may gain "associational resistance" when the defended plants are protected from herbivory by nearby plants (Tahvanainen \& Root 1972; Rausher 1981; Hambäck et al. 2000). In the polyculture of the collard green Brassica oleracea var. acephala (Brassicaceae), Root and colleagues for the first time developed the concept of "associational resistance" and "resource concentration," which refer to the effects of vegetation composition and total density on 
97 herbivore populations, respectively (Tahvanainen \& Root 1972; Root 1973). Recently, it

98 was also discovered that neighboring plants do not always reduce herbivory damage to

99 other plant species. The term "associational susceptibility" was coined to refer to the

100 situation where defended plants suffer from severe herbivory when they occur nearby

101 undefended ones (White \& Whitham 2000; Rand 2003). Barbosa et al. (2009) introduce

102 many more examples of AE and Rautio et al. (2012) outline the terminology regarding

103 AE, comprising the terms "plant defense guild" (Atsatt \& O’Dowd 1976), "shared

104 doom" (Wahl \& Hay 1995; Emerson et al. 2012), and "associational refuge" (Hjältén et

105 al. 1993; Miller et al. 2009; Emerson et al. 2012; Hughes 2012).

106 The mechanisms underlying AE are involved in various combinations of plant

107 traits and herbivore behaviors. In general, herbivores alter their preferences and/or

108 performance depending on their dietary menu (e.g., Lefcheck et al. 2013; Sato \& Kudoh

109 2016a; Wetzel et al. 2016). In particular, theory of optimal foraging suggests that

110 consumers should utilize suboptimal resource as the density of optimal resource

111 becomes low (e.g., Charnov 1976). This behavioral basis of consumers directly alters

112 the consumption rate and thus drives apparent competition between optimal and

113 suboptimal resource (Holt \& Kotler 1987). Empirically, mammalian herbivores often

114 avoid spiny or toxic herbs and thereby lead these defended herbs to confer associational

115 resistance to undefended plant species at a patch level (e.g., Hjältén et al. 1993;

116 Callaway et al. 2005; Courant \& Fortin 2010; Miller et al. 2009). Visual or chemical

117 crypsis conferred by neighboring plants results in associational resistance against insect

118 herbivores (Tahvanainen \& Root 1972; Rausher 1981; Hambäck et al. 2000). Volatile

119 organic chemicals from neighboring plants sometimes induce plant resistance traits and

120 thus drive associational resistance against herbivores (Karban \& Maron 2002; Karban 
121 2007; Zakir et al. 2013). Direct competition sometimes increases plants' investment in

122 defense traits and may promote associational resistance (Barton \& Brower 2006;

123 González-Teuber \& Gianoli 2007). Polyphagous herbivores move from primary to

124 secondary host species during their dispersal process, resulting in associational

125 susceptibility on the part of the former to the latter host plant (White \& Whitham 2000;

126 Agrawal 2004). These examples suggest that the outcomes of AE depend on herbivore

127 behaviors and plant trait changes.

128 While long recognized as apparent competition, the outcomes of AE are more

129 complex than simple competition between two plant species. AE comprise facilitation,

130 exploitation, and other kinds of species interaction (Agrawal 2004; Barbosa et al. 2009).

131 In particular, recent reviews pointed out problems with the terminologies and

132 experimental designs used to test AE (Rautio et al. 2012; Underwood et al. 2014), as

133 there has been little consensus regarding the trait of a focal plant type (i.e., defended or

134 undefended) and manipulations on the neighborhood composition (presence/absence,

135 relative abundance, or total density of multiple plant types) (see also Appendix). For

136 example, a number of studies compared the magnitude of herbivory on one of two plant

137 species between the presence and absence of another species (Hambäck et al. 2000;

138 White \& Whitham 2000); however, this setting is unable to determine the likelihood of

139 the coexistence of two plant species (Underwood et al. 2014). Many studies focused on

140 the absolute amount of herbivory (Tahvanainen \& Root 1972; Hambäck et al. 2000;

141 White \& Whitham 2000), while others compared the relative amounts of herbivory

142 between multiple plant types (Bergvall et al. 2006; Castagneyrol et al. 2013).

143 Furthermore, some studies focused on the herbivory load to individual plants within a

144 small spatial scale (referred to as a "patch": Rausher 1981; Hambäck et al. 2000; 
145 Karban \& Maron 2002) while others compared herbivory among the plant patches at

146 broader spatial scales (Bergvall et al. 2006; Castagneyrol et al. 2013). Details of the

147 experimental design and outcomes are listed for 16 publications (see Appendix).

149 1-2. Frequency/density-dependent damage caused by $A E$

150 Recently, several authors have begun to discuss how AE enable the coexistence of

151 multiple plant species. Underwood et al. (2014) advocated that the focus should be on

152 the frequency- or density-dependent damage caused by AE to multiple plant species. If

153 AE is more likely to protect rare plant species than abundant species, this rarity

154 advantage (i.e., negative frequency dependence) in defense would prevent rare species

155 from going extinct due to herbivory, thereby promoting the coexistence of multiple

156 plant species. In this refined framework, negative or positive frequency-dependent

157 damage indicates associational resistance or susceptibility for rare plant species,

158 respectively. Even if multiple plant species can coexist via AE, recovery from low

159 density (i.e., negative density dependence) is necessary for the long-term persistence of

160 plant populations. The negative or positive density-dependent damage refers to the

161 "resource concentration or delusion" hypothesis, initially developed by Root (1973) and

162 recently reviewed by Underwood et al. (2014) and Hambäck et al. (2014).

163 Several studies suggest the importance of plant frequency and density in

164 determining the outcome of $\mathrm{AE}$, although those showing the importance of both the

165 density and frequency dependence are still limited (Table 1). Kim and Underwood

166 (2015) manipulated the density and frequency of the tall goldenrod Solidago altissima

167 (Asteraceae) and the Carolina horsenettle Solanum carolinense (Solanaceae). As a result,

168 S. carolinense received more damage due to the combined effects of the high 
169 conspecific density and intermediate frequency of the two species (Kim \& Underwood

170 2015). Hahn and Orrock (2016) manipulated both the density and frequency of two

171 related species Solidago nemoralis and S. odora (Asteraceae) in the field and then

172 revealed herbivore foraging to be a key mechanism with a behavioral assay. The less

173 defended species $S$. nemoralis gained associational resistance when it was rare due to

174 the reduced foraging activity of grasshoppers, with the two Solidago species more likely

175 attacked at a higher density (Hahn \& Orrock 2016). In relation to herbivore foraging,

176 Verschut et al. (2016) showed that low-concentration of balsamic vinegar was less

177 likely to attract the fruit fly Drosophila melanogaster at a high frequency of high

178 concentration diets, while high-concentration diets were more likely to attract flies at a

179 high frequency of low-concentration diets. Previous studies on the fallow deer Dama

180 dama manipulated the tannin concentration as well as the frequencies of two resource

181 types (Bergvall \& Leimar 2005; Bergvall et al. 2006). High tannin diets were consumed

182 less frequently when low tannin diets were abundant, whereas low tannin diets were

183 consumed more frequently when high tannin diets were abundant (Bergvall \& Leimar

184 2005). Furthermore, if two species co-occur in their natural habitats, field surveys help

185 us capture the effects of plant density or frequency in the wild population. Russell and

186 Louda (2005) documented that the native thistle Cirsium undlatum (Asteraceae)

187 received less florivory from the exotic weevil Rhinocyllus conicus as the number of

188 another native thistle (C. canescens) increased in close vicinity. This long-term survey

189 found that an invasive herbivore creates a novel AE due to the overlap of flowering

190 phenology between two native plant species (Russell \& Louda 2004; Russell \& Louda 191 2005). 
193 experimentally, we still know little about how AE occurs and contributes to the

194 maintenance of plant species diversity. Thus, it is necessary to link the mechanisms and

195 patterns of AE in a single study system. There is a common set of empirical approaches

196 for understanding the mechanisms and consequences of AE from laboratory to the field

197 study (Fig. 1: see also Appendix for details). The first step is to discover candidate

198 mechanisms of AE (Fig. 1), including the identification of key plant traits and herbivore

199 behaviors, and then to address how they cause non-additive herbivory between multiple

200 plant species. Previous studies have done this by conducting laboratory choice

201 experiments (e.g., Tahvanainen \& Root 1972; White \& Whitham 2000; Rand 2003) or

202 by observing herbivore movements between plants (Rausher 1981; Bergvall et al. 2006).

203 The second step includes experimental tests to determine whether plant damage and/or

204 fitness depend on the neighborhood composition. This step is adopted by almost all the

205 studies and is the most important for illustrating the relevance of AE. The third step is

206 multi-year field survey to corroborate the experimental evidence with field observations

207 on plant damage and population dynamics across years (Fig. 1). This final step is

208 executable if the focal plant species co-occur within natural populations (Russell \&

209 Louda 2004; Callaway et al. 2005). These comprehensive tests from laboratory

210 experiment to field observations will reveal the causes and consequences of AE in a

211 single study system.

212

213 1-3. Plant defense polymorphism via the lens of conspecific AE

214 While the concept of AE was originally developed in interspecific interactions

215 (Tahvanainen \& Root 1972; Root 1973), it can be applied to genetic variation within the

216 same plant species. In agricultural ecosystems, polyculture has been carried out not only 
217 for different species but also for different cultivars within the same plant species (e.g.,

218 Cantero \& Sanford 1984; Hambäck et al. 2009). The emerging framework of

219 "community genetics" may be considered a kind of conspecific AE (Hughes et al. 2008),

220 as these studies have shown that the polyculture of different genotypes alters herbivore

221 abundance (e.g., Crutsinger et al. 2006; Johnson et al. 2006; Parker et al. 2010). Studies

222 on community genetics also revealed that plant genetic diversity altered the strength of

223 selection on plant genotypes via changes in plant-herbivore interaction (e.g., Johnson et

224 al. 2006; Lankau \& Kliebenstein 2009; Parker et al. 2010), although the way in which

225 frequency-dependent selection occurs between plant genotypes remains to be explored.

226 Evolutionary game theory provides a logical basis for the roles of AE in

227 maintaining polymorphism in defense levels (Sabelis \& de Jong 1988; Augner et al.

228 1991; Till-Bottraud \& Gouyon 1992; Tuomi et al. 1999). Theoretical studies analyzed

229 conditions under which the benefits from AE and the intrinsic cost of defense allow

230 defended and undefended plants to coexist. In clonal plants, for example, Till-Bottraud

231 and Gouyon (1992) predicted that herbivore preference and the cost of defense lead to

232 the evolutionary stable strategy of producing cyanogenic and acyanogenic clones at an

233 intermediate frequency. Empirically, this hypothesis regarding evolutionary stability can

234 be tested by asking whether or not rarer plant types have higher fitness compared to

235 abundant ones under AE (reviewed by Rautio et al. 2012). If a rarity fitness advantage

236 reciprocally occurs among multiple plant genotypes, AE leads to negative

237 frequency-dependent selection that can prevent rare genotypes from going extinct

238 (Clarke 1964; Ayala \& Campbell 1974). This criterion would allow empirical

239 researchers to test whether AE can be a mechanism maintaining polymorphism in

240 antiherbivore defense. 
with regard to the maintenance of polymorphism in antiherbivore defense (Table 1).

243 Wise et al. (2009) tested AE in the tall goldenrod Solidago altissima, which possesses a

244 genetically based phenotype of ducking stem (called the "candy-cane" morph). This

245 candy-cane morph occurs with a rare frequency but across natural populations of $S$.

246 altissima (Wise 2009). Wise et al. (2009) conducted a manipulative experiment with

247 two contrasting frequencies of candy-cane and erect-stem morphs (Table 1). The tall

248 goldenrod received less damage from the specialist gall fly Eurosta solidaginis when

249 the candy-cane morphs were abundant; however, the damage was frequency

250 independent, as shown by the lack of a significant morph-by-frequency interaction

251 (Wise et al. 2009). Recently, Garrido et al. (2016) tested frequency-dependent selection 252 between tolerant (i.e., defense mitigating negative effects of herbivory on plant fitness)

253 and resistant (defense directly reducing herbivore attacks) genotypes in the jimson weed

254 Datura stramonium (Solanaceae), but found a rarity "disadvantage" against the

255 maintenance of defense polymorphism. Thus, it remains unknown whether conspecific

256 AE can be a mechanism for the maintenance of defense dimorphism. My collaborators

257 and I have investigated AE against a leaf beetle in the trichome dimorphism of

258 Arabidopsis halleri subsp. gemmifera (Brassicaceae). In the next chapter, I will

259 introduce an example of conspecific AE and its stabilizing effect on a plant defense

260 polymorphism.

\section{Evidence}

263 Several species of the genus Arabidopsis exhibit a dimorphism of trichome-producing 264 (hairy) and trichomeless (glabrous) plants. The glabrousness of Arabidopsis species is 
265 associated with the loss of function of the key gene of trichome development,

266 GLABRA1 (GL1 also known as GLABROUS1) (Hauser et al. 2001; Kivimäki et al.

267 2007; Kawagoe et al. 2011; Bloomer et al. 2012). Because GL1 is a transcriptional

268 factor gene for the initiation of trichome development, the loss of function of this gene

269 results in distinct phenotypes of hairy and glabrous plants (Oppenheimer et al. 1991;

270 Hülskamp 2004; Ishida et al. 2008). The glabrous phenotype is recessive to the hairy

271 ones, and these phenotypes are inherited in the Mendelian fashion (Kärkkäinen \& Ågren

272 2002). Laboratory studies and field surveys have shown that hairy plants incurred less

273 herbivory by insect herbivores compared to glabrous plants (Handley et al. 2005;

274 Sletvold et al. 2010; Løe et al. 2007; Kivimäki et al. 2007), while trichomes impose a

275 fitness cost on plants (Mauricio 1998; Sletvold et al. 2010; Züst et al. 2011). Owing to

276 the visible and discrete phenotypes with the antiherbivore function, Arabidopsis

277 trichomes provide an excellent system to investigate AE against herbivores within a

278 same-plant species.

279

Likewise, Arabidopsis halleri subsp. gemmifera (abbreviated hereafter as A.

280 halleri) have a dimorphism of hairy and glabrous plants (Fig. 2a). Hairy plants have

281 non-glandular trichomes on their leaves and stems, whereas glabrous plants produce no

282 trichomes, except on their stem and leaf margin. This presence/absence of leaf

283 trichomes is associated with the allelic status of a GL1 orthologue (Kawagoe et al.

284 2011). Hairy plants showed a lower fecundity and slower growth than glabrous ones did

285 in the absence of herbivores (Kawagoe et al. 2011; Sato \& Kudoh 2016b; Sato \& Kudoh

286 2017b), indicating a fitness cost of the trichome production. Further, trichome

287 production is unlinked with glucosinolate profiles (Sato et al. 2014), which may act as a

288 chemical defense for Brassicaceae (e.g., Züst et al. 2012). 
290 distributed across Japan and the Russian Far East. Plants bloom from early April to May

291 at the lowland of Japan (Kawagoe \& Kudoh 2010). Flowers are pollinated by hoverflies

292 and solitary bees. Seeds are dispersed by gravity. After flowering, plants produce clonal

293 rosettes on the main and lateral meristems (Sato \& Kudoh 2017b), wherein late-spring

294 herbivory can directly affect the sexual and asexual reproduction. Arabidopsis halleri

295 subsp. gemmifera is attacked by multiple species of herbivorous insects including

296 beetles, butterflies, and sawflies from late-spring to early-summer (Sato \& Kudoh 2015;

297 Sato \& Kudoh 2017a). Among natural populations of A. halleri, the brassica leaf beetle,

298 Phaedon brassicae (Fig. 2a), occasionally outbreaks and impacts fruit production by

299 heavily infesting flowering stems (Kawagoe \& Kudoh 2010).

300 In this second chapter, I introduce a case study of conspecific AE against the

301 leaf beetle on the trichome dimorphism of $A$. halleri. This study consists of three

302 specific approaches (Fig. 2). The first stage is to identify candidate mechanisms of

303 frequency-dependent damage between hairy and glabrous plants. In the second stage,

304 manipulative experiments are conducted to test fitness consequence and to address

305 whether AE against the leaf beetle results in negative frequency-dependent selection

306 between the two morphs. The final step is to link the experimental findings with field

307 observations by modeling mechanisms that govern plant population dynamics. These

308 three steps will provide comprehensive evidence that AE play a stabilizing role in plant

309 defense polymorphism.

310

\section{2-1. Candidate mechanisms of $A E$}

312 Behavioral response of herbivores to multiple resources can be a mechanism of AE (e.g., 
313 Bergvall et al. 2006; Verschut et al. 2016; Hahn \& Orrock 2016). Choice assays are

314 often conducted to test the candidate mechanism of AE (Tahvanainen \& Root 1972;

315 White \& Whitham 2000; Rand 2003; Hahn \& Orrock 2016). Several studies

316 documented that the feeding preferences of herbivores depend on the presence or

317 relative frequencies of multiple resource types (Chandra \& Williams 1983; Cottam

318 1985; Behmer et al. 2001; Bergvall \& Leimar 2005; Janz et al. 2005), but evidence

319 regarding such a frequency-dependent herbivory on natural variation in a plant defense

320 trait is limited.

My collaborators and I have conducted a four-way choice experiment

322 manipulating frequencies of hairy and glabrous leaf discs (Fig. 2b: Sato et al. 2014).

323 Adults of the brassica leaf beetle P. brassicae avoided hairy leaves when hairy leaves

324 were rare, whereas the adults did not show a feeding preference when hairy leaves

325 became abundant (Sato et al. 2014). The adult preference for glabrous leaves was also

326 observed in a binary choice experiment using a gll mutant of the model plant species

327 Arabidopsis thaliana (Sato 2016). This result from a single-gene mutant provides strong

328 proof for the resistance function of the $G L 1$ gene against $P$. brassicae. Furthermore,

329 when adult beetles were starved or preconditioned with glabrous diets, they still

330 preferred glabrous plants (Sato \& Kudoh 2016b). Contrarily, when adults were

331 preconditioned with hairy diets, this treatment weakened their feeding preference for

332 glabrous diets (Sato \& Kudoh 2016b). The circumstantial evidence suggests that

333 sequential experience may trigger a non-random response of adult beetles to hairy and

334 glabrous diets. While adult beetles fed on both hairy and glabrous leaves at similar

335 levels under no-choice conditions, larvae fed on hairy diets grew slower than those on

336 glabrous diets. This indicates that hairy diets are suboptimal for P. brassicae. 
The foraging behaviors of $P$. brassicae were then modeled to reveal the

338 mechanism underlying the pattern of leaf damage to hairy and glabrous plants. Given

339 that $P$. brassicae is flightless and incapable of selecting plants among patches, the

340 optimal diet choice (Charnov 1976) is assumed to be a mechanism by which rare

341 suboptimal diets (i.e., hairy leaves) are less consumed under the small enclosed

342 condition. My collaborators and I modified the original model of optimal diet choice to

343 consider imperfect host recognition by $P$. brassicae, and then fitted the model to the

344 laboratory experiment data of leaf damage under the contrasting frequency of hairy and

345 glabrous plants (Sato et al. 2017). As a result of the parameter estimation, it was

346 estimated that decreased energy intake and increased handling time for the leaf beetles

347 accounted for the frequency-dependent damage on hairy plants (Fig. 2c). Hairy plants

348 were less damaged when glabrous plants became abundant, indicating associational

349 resistance for hairy plants. Contrarily, damages to glabrous plants weakly depended on

350 the frequency of two plant morphs. These findings indicate that the optimal diet choice

351 by P. brassicae can be a determinant of the pattern of AE between hairy and glabrous

352 plants.

354 2-2. Manipulative experiment showing a rarity advantage in plant defense and fitness

355 Even if herbivores feed on hairy and glabrous plants in a frequency-dependent manner,

356 it is still unknown whether this candidate mechanism leads to frequency-dependent

357 selection on the trichome dimorphism. Specifically with regard to the brassica leaf

358 beetle $P$. brassicae, it seems unlikely that herbivore preference alone generates negative

359 frequency-dependent selection, as they did not avoid rare glabrous diets (Sato et al.

360 2014: Fig. 3a). However, game theoretical models suggest that, if plants have defense 
361 traits at the cost of their growth or fecundity, the benefit from associational effects

362 allows defended and undefended plants to coexist (Augner et al. 1991). This hypothesis

was tested using a laboratory and semi-field experiment manipulating the morph

364 frequency and presence/absence of P. brassicae (Fig. 2b; Sato \& Kudoh 2016b; Sato \&

365 Kudoh 2017b).

$366 \quad$ Figure 3 shows a schematic explanation of a mechanism by which conspecific

367 AE could be a mechanism for the maintenance of trichome dimorphism. Consistent with

368 the feeding preference assay (Sato et al. 2014), hairy plants were less damaged than

369 glabrous plants only when the hairy ones were rare (Fig. 3a: Sato \& Kudoh 2016b; Sato

370 \& Kudoh 2017b). This explains the rarity advantage for hairy plants in defense and

371 fitness (Fig. 3a, c). At the end of the experiments, both the hairy and glabrous plants had

372 a rarity advantage in fitness in the presence of beetles (Fig. 3c: Sato \& Kudoh 2016b;

373 Sato \& Kudoh 2017b), while in the absence of herbivory the glabrous plants had a

374 higher growth and fecundity (Fig. 3b: Sato \& Kudoh 2016b; Sato \& Kudoh 2017b).

375 Because the benefit of associational effects to hairy plants no longer exists under the

376 hairy-abundant condition (Fig. 3a), the cost of defense can be detected when hairy

377 plants become abundant (Fig. 3c). Of note, these fitness consequences were consistently

378 observed for both sexual and asexual reproduction, namely the number of flowers and

379 clones, of $A$. halleri (Sato \& Kudoh 2017b). These experimental findings indicate that,

380 together with the defense-growth tradeoff (Fig. 3c), conspecific AE against the leaf

381 beetle (Fig. 3a) lead to negative frequency-dependent selection between hairy and

382 glabrous plants (Fig. 3b) (Sato \& Kudoh 2017b). 
385 The set of experiments illustrated conspecific AE that can maintain the trichome

386 dimorphism of $A$. halleri, but it is still unknown whether these experimental findings represent $\mathrm{AE}$ in the wild. Next, field observations on plant damage and demography were conducted in a natural population in which the brassica leaf beetle P. brassicae was a major herbivorous insect on A. halleri (Fig. 2b). Because P. brassicae is flightless and the A. halleri population has a fragmented structure, AE is assumed to occur on a small spatial scale. Thus, my collaborators and I tracked the aggregated structure of the plants (referred to hereafter as "patch") for four years in the field.

394 in a series of plant patches (Sato et al. 2014; Sato \& Kudoh 2017b). In contrast, leaf 395 damage on glabrous plants showed no significant and consistent relationship with the 396 frequency of glabrous plants in a patch (Sato et al. 2014; Sato \& Kudoh 2017b). This 397 pattern of leaf damage was consistent with the results of a feeding assay. It was also 398 noteworthy that the relative fitness advantage of hairy plants as shown by flower 399 production in the presence of beetles increased with increasing frequencies of glabrous 400 plants (Sato \& Kudoh 2017b). This pattern in the flower production agrees with the manipulative experiment detecting negative frequency-dependent selection only in the presence of P. brassicae (Fig. 3c). These findings support the relevance of

403 frequency-dependent herbivory and selection in the natural population. A multi-year field survey also found that rarer morphs increased in frequency 405 in a series of plant patches over time (Sato \& Kudoh 2017b). Statistical modeling was 406 used to reveal the mechanisms underlying the temporal dynamics of morph frequency in 407 the field (Sato et al. 2017). Based on the aforementioned theory of optimal diet choice, 408 my collaborators and I have modelled the effects of local-scale herbivory and spatial 
409 structure on plant demography and then fitted the model to the observed changes in the number of hairy and glabrous plants over four years. Based on a model selection

411 procedure, it was revealed that optimal diet choice by $P$. brassicae contributes to the

412 polymorphism dynamics observed in the field (Sato et al. 2017). The estimated

413 magnitude of interpatch dispersal suggested that long-distance seed dispersal was rare

414 and clonal reproduction largely contributed to the plant population growth. According to

415 the estimated parameters of antiherbivore defense, rarer morphs had higher fitness and

416 increased in frequency over time when the herbivore diet choice and cost of plant

417 defense were both involved (Fig. 2c). This joint approach using the optimality modeling

418 and field data strongly supports the hypothesis that AE against the leaf beetle promotes

419 the maintenance of the trichome dimorphism via negative frequency-dependent

420 selection.

421 In contrast to the constant density in the manipulative experiment (Fig. 3), not

422 only frequency but also the number of plants varies among field patches. However, the

423 effects of plant density on damage were much less significant than that of frequency,

424 and its magnitude and direction were inconsistent among the study years (Sato et al.

425 2014; Sato \& Kudoh 2017b). The resource concentration or delusion of A. halleri for $P$.

426 brassicae was tested in more detail using the field data on the leaf damage and number

427 of A. halleri plants (Sato et al. 2017). If these two effects of plant density occur, there is

428 a non-linear relationship between the total amount of herbivory load and the total

429 number of plants within patches (Hambäck et al. 2014). In A. halleri, however, the total

430 amount of leaf damage increased linearly with the total number of plants in a patch

431 (Sato et al. 2017), presumably because the plant density in the field was too low to

432 reach a peak of resource loss by herbivory. Thus, at least for the temporal scales 
433 observed, the field survey could not detect a significant role of plant density in AE

434 against the leaf beetles.

435 Overall, the multiple lines of evidence have shown that conspecific AE

436 mediated by P. brassicae lead to negative frequency-dependent selection and thereby

437 maintain the trichome dimorphism in a natural A. halleri population. If hairy plants are

438 rare, they can escape from leaf beetles and increase in frequency. On the other hand, if

439 glabrous plants become rare, they outcompete hairy plants without any costs of

440 trichomes. Consequently, this negative feedback loop prevents rare morphs from going

441 extinct (Fig. 4). To date, negative frequency-dependent selection has been reported for

442 plant species interacting with pollinators (Gigord et al. 2001) and pathogens

443 (Antonovics \& Ellstrand 1984; Brunet \& Munht 2000), but it has not yet been

444 demonstrated in plant defense against herbivores. The case study on A. halleri-P.

445 brassicae interaction provides the first example to illustrate that conspecific AE drive

446 negative frequency-dependent selection on an antiherbivore defense trait.

\section{3. Perspective}

449 Genetic polymorphisms are commonly observed in plant defense traits (Hughes 1991;

$450 \quad$ Elle et al. 1999; Wise et al. 2009; Bernhardsson et al. 2013) and not limited to

451 Arabidopsis trichomes. For example, the genetic basis of cyanogenesis in white clover

452 Trifolium repens (Fabaceae) is well studied (Hughes 1991). Theory related to

453 herbivore-mediated frequency-dependent selection was applied to geographical

454 variation in a cyanogenesis polymorphism (Till-Bottraud \& Gouyon 1992), but the

455 existence of frequency-dependent selection has not been tested experimentally.

456 Dimorphism of the glandular (sticky) and non-glandular (velvety) Datura wrightii 
457 (Solanaceae) is inherited in the Mendelian fashion (van Dam et al. 1999). This chemical

458 defense utilizing glandular exudates is costly for plant fitness (Elle et al. 1999), but it

459 remains unknown why these sticky and velvety plants can coexist (Elle \& Hare 2000).

460 The genetic basis of glucosinolates, a major secondary metabolite of Brassicales, has

461 been intensively studied. Genetic polymorphisms are observed in physiological

462 pathways in glucosinolate biosynthesis and result in diverse profiles among natural

463 Arabidopsis accessions (Chan et al. 2010). Conspecific AE have not yet been examined

464 in these defense traits but could provide insights into mechanisms for the maintenance

465 of antiherbivore defense polymorphism within a plant population.

466 We should note here that not only AE but also other factors may shape genetic

467 variation in antiherbivore defenses. It has been hypothesized that genetic variation may

468 be maintained by spatiotemporal fluctuation in selection pressure and stochastic gene

469 flow among populations (e.g., Levene 1953; Turelli et al. 2001; but see Spichtig \&

470 Kawecki 2004). The present paper has focused on local-scale AE so far, but to what

471 spatial and temporal scales can AE contribute to the maintenance of polymorphism in

472 plant defense? In the final chapter, I discuss a spatial and temporal perspective of

473 conspecific AE and the maintenance of plant defense polymorphism. Concerning the

474 spatial scale, several researchers discussed interspecific AE at a landscape scale

475 (reviewed by Barbosa et al. 2009). The geographic mosaic of coevolution (Thompson

476 2005) proposes a landscape perspective of plant-insect interactions, and this spatial

477 point of view is applied to geographic variation in plant defense (e.g., Berenbaum \&

478 Zangerl 1998; Zangerl \& Berenbaum 2003; Toju et al. 2011; Bernhardsson et al. 2013).

479 In particular to temporal dynamics, the concept of eco-evolutionary dynamics has

480 recently suggested interactions between plant genetic variation and herbivore abundance 
481 (Turcotte 2011; Turcotte et al. 2013; Agrawal et al. 2013). Because not only frequency-

482 but also density-dependent selection is a key aspect of AE (Table 1), conspecific AE

483 may provide insights into how rapid evolution in plant defenses affects the population

484 dynamics of plants and herbivores.

485

3-1. Can AE create a source population for geographical variation in plant defense?

487 Existing theory suggests that negative frequency-dependent selection contributes to geographic cline in a polymorphism, as it makes morph frequency intermediate rather than expected by the results of disruptive selection alone (Clarke 1966; Endler 1977; Till-Bottraud \& Gouyon 1992). Till-Bottraud \& Gouyon (1992) applied this prediction to explain a cyanogenesis polymorphism along an altitudinal cline in white clover.

492 However, herbivory regimes usually have more complex spatial patterns than a cline, 493 involving differences in herbivore species (Hare \& Elle 2002) and the presence of other 494 host plants (Zangerl \& Berenbaum 2003). Thus, plant-herbivore interactions are expected to result in complex geographic variation rather than a simple cline in a plant defense polymorphism.

The geographic mosaic of coevolution proposes a conceptual framework for investigating the complex metapopulation structure of local adaptation/maladaptation

499 (Thompson 2005). Specifically, the theory of geographic mosaic of coevolving

500 polymorphism hypothesizes that disruptive and balancing selection jointly shape

501 complex patterns of host defense polymorphism (Thompson 2005). In plant-herbivore 502 interactions, Berenbaum and Zangerl (1998) presumed that intense attacks by parsnip 503 webworm Depressaria pastinacella on abundant chemotypes of a wild parsnip 504 Pastinaca sativa (Apiaceae) led to negative frequency-dependent selection and thus 
505 favored the intermediate chemotype frequency. Given that AE should occur among

506 individual plants in close vicinity, this may alter spatial patterns of plant defense only at

507 a local scale. More generally, the metapopulation framework assumes the existence of

508 source and sink populations of local adaptation (Thompson 2005). When AE favors

509 polymorphism within a local population, this polymorphic population could be a source

510 of polymorphism on a metapopulation scale via gene flow (Fig. 5). Indeed, herbivore regimes and frequencies of hairy and glabrous plants vary

512 among natural populations of Arabidopsis halleri subsp. gemmifera, where AE do not

513 occur against all herbivorous insects on A. halleri. Sato and Kudoh (2015) found that

514 AE were detectable when $A$. halleri interacted with slow-moving herbivores such as $P$.

515 brassicae. AE tend to be obscured when plants are attacked by flying herbivores such as

516 the green-veined white butterfly Pieris napi and cabbage sawfly Athalia infumata,

517 although trichomes themselves can prevent herbivory by these herbivores (Sato \&

518 Kudoh 2015). Field surveys revealed that frequencies of glabrous plants declined as

519 herbivory pressure became intense (Sato \& Kudoh 2017a). Hairy-monomorphic

520 populations were discovered where white butterflies were frequently observed. Despite

521 experiencing the severest herbivory pressure, however, a population where $P$. brassicae

522 was predominant still had an intermediate morph frequency (Sato \& Kudoh 2017a).

523 Furthermore, a proximate population was also polymorphic despite the prevalence of

524 white butterflies (Sato \& Kudoh 2017a). These observations support the hypothesis that

525 herbivore-mediated frequency-dependent selection sustains polymorphism, which can

526 be a source of genetic variation in proximate populations (Fig. 5b). Further questions

527 remain about how conspecific AE contributes to the maintenance of polymorphism at

528 the metapopulation level. 
530 3-2. Do AE affect population dynamics via the maintenance of defense polymorphism?

531 A growing number of studies have shown that herbivores drive the evolution of plant

532 defense on ecological time scales (Zangerl \& Berenbaum 2008; Agrawal et al. 2012;

533 Fukano \& Yahara 2012; Sakata et al. 2014). Recent studies have also shown that such

534 evolutionary changes in a host plant species alter the population dynamics and

535 community structures of herbivores (Crutsinger et al. 2006; Johnson et al. 2006;

536 Turcotte et al. 2011; Agrawal et al. 2013), which may in turn affect plant density. Now

537 that conspecific $\mathrm{AE}$ is known to maintain polymorphism in plant defense, it is possible

538 that such a sustained polymorphism affects eco-evolutionary dynamics in

539 plant-herbivore interactions. In the context of AE, Underwood et al. (2014) advocate

540 that manipulating both the density and frequency of multiple plant species is important

541 for complete understanding of the long-term coexistence of multiple plant species under

542 AE (as introduced in Section 1-2.). When this notion is applied to polymorphisms

543 within a plant species, AE may play an important role not only through frequency- but

544 also through density-dependent selection in plant defense.

545 Once the mechanisms of frequency- and/or density-dependent selection are

546 experimentally shown, it is possible to estimate the probability of coexistence from the

547 experimental data (e.g., Damgaard 1998; Inouye 2001; Miller \& Rudgers 2014) or to

548 predict temporal dynamics in the field (Kim et al. 2013; Le Rouzic et al. 2015) based on

549 a given theoretical model. This modeling approach, combined with empirical data, will

550 be a powerful tool to reveal how AE contribute to eco-evolutionary dynamics in

551 plant-herbivore interactions. For example, Sato et al. (2017) took such a modeling

552 approach to $A$. halleri-P. brassicae interactions although the modeling was limited in 
553 predicting long-term interactions between the evolution of plant defenses and herbivore

554 population dynamics. Specifically, the magnitude of herbivory in the current year was

555 not clearly correlated with that in the previous year or with the frequency of hairy plants

556 (Sato et al. 2017). If long-term data on herbivory and population dynamics are obtained,

557 the modeling approach might enable us to predict how the existence of polymorphism

558 affects herbivory pressure and in turn alters the morph frequency within a plant species.

559

\section{3-3. Concluding remarks}

561 Associational effects, or neighbor effects, are remarkable phenomena in plant-herbivore

562 interaction, but evidence for conspecific $\mathrm{AE}$ is still limited. By focusing on polymorphic

563 defense traits within a plant species, the present review highlights the potential

564 importance of conspecific $\mathrm{AE}$ in maintaining polymorphism in an antiherbivore defense trait. The multiple lines of evidence from P. brassicae-A. halleri interaction show that conspecific AE maintains antiherbivore defense polymorphism via negative

567 frequency-dependent selection. Future studies should focus on the stabilizing role of AE

568 in genetic variation in plant defense, as diverse plant species possess considerable

569 variation in terms of antiherbivore defense traits.

571 Acknowledgements - I would like to express my deep appreciation to Prof. H. Kudoh

572 for his support of my $\mathrm{PhD}$ studies. I am also grateful to all the researchers from the

573 Center for Ecological Research, Kyoto University, and particularly to Drs. Y. Sakata, K.

574 Ito, and T. Kawagoe for discussions and comments during the study. I sincerely thank

575 the Society for the Study of Species Biology for the honor of receiving the Kataoka

576 Award; editors, Drs. M. Ohara and K. Kitamura, for kind invitation and editorial 
assistance; and two anonymous reviewers for helpful comments on the manuscript. This study is partly supported by JSPS Research Fellowship to Y. Sato (Grant numbers 15J00400 and 16J30005).

\section{References}

Agrawal, A.A. (2004) Resistance and susceptibility of milkweed: competition, root herbivory, and plant genetic variation. Ecology 85:2118-2133.

Agrawal, A.A., Lau, J.A. \& Hambäck, P.A. (2006) Community heterogeneity and the evolution of interactions between plants and insect herbivores. Quarterly Review of Biology 81:349-376.

Agrawal, A.A., Hastings, A.P., Johnson, M.T.J., Maron, J.L. \& Salminen, J.-P. (2012) Insect herbivores drive real-time ecological and evolutionary change in plant populations. Science 338:113-116.

Agrawal, A.A., Johnson, M.T., Hastings, A.P. \& Maron, J.L. (2013) A field experiment demonstrating plant life-history evolution and its eco-evolutionary feedback to seed predator populations. The American Naturalist 181:S35-S45.

Antonovics, J. \& Ellstrand, N.C. (1984) Experimental studies of the evolutionary significance of sexual reproduction. I. A test of the frequency-dependent selection hypothesis. Evolution 38:103-115.

Atsatt, P.R. \& O’Dowd, D.J. (1976) Plant defense guilds. Science 193:24-29.

Augner, M., Fagerström, T. \& Tuomi, J. (1991) Competition, defense and games between plants. Behavioral Ecology and Sociobiology 29:231-234.

Ayala, F.J. \& Campbell, C.A. (1974) Frequency-dependent selection. Annual Review of Ecology and Systematics 5:115-138.

Barbosa, P., Hines, J., Kaplan, I., Martinson, H., Szczepaniec, A. \& Szendrei, Z. (2009) Associational resistance and associational susceptibility: having right or wrong neighbors. Annual Review of Ecology, Evolution, and Systematics 40:1-20.

Barton, K.E. \& Bowers, M.D. (2006) Neighbor species differentially alter resistance phenotypes in Plantago. Oecologia 150:442-452. 
608 Behmer, S.T., Raubenheimer, D. \& Simpson, S.J. (2001) Frequency-dependent food

609

610

611

612

613

614

615

616

617

618

619

620

621

622

623

624

625

626

627

628

629

630

631

632

633

634

635

636

637

638

639

selection in locusts: a geometric analysis of the role of nutrient balancing. Animal Behaviour 61:995-1005.

Berenbaum, M.R. \& Zangerl, A.R. (1998) Chemical phenotype matching between a plant and its insect herbivore. Proceedings of the National Academy of Sciences USA 95:13743-13748.

Bergvall, U.A. \& Leimar, O. (2005) Plant secondary compounds and the frequency of food types affect food choice by mammalian herbivores. Ecology 86:2450-2460.

Bergvall, U.A., Rautio, P., Kesti, K., Tuomi, J. \& Leimar, O. (2006) Associational effects of plant defences in relation to within-and between-patch food choice by a mammalian herbivore: neighbour contrast susceptibility and defence. Oecologia 147:253-260.

Bernhardsson, C., Robinson, K.M., Abreu, I.N., Jansson, S., Albrectsen, B.R. \& Ingvarsson, P.K. (2013) Geographic structure in metabolome and herbivore community co-occurs with genetic structure in plant defence genes. Ecology letters 16:791-798.

Bloomer, R.H., Juenger, T.E. \& Symonds, V.V. (2012) Natural variation in GL1 and its effects on trichome density in Arabidopsis thaliana. Molecular Ecology 21:3501-3515.

Brunet, J. \& Mundt, C.C. (2000) Disease, frequency-dependent selection, and genetic polymorphisms: experiments with stripe rust and wheat. Evolution 54:406-415.

Callaway, R.M., Kikodze, D., Chiboshvili, M. \& Khetsuriani, L. (2005) Unpalatable plants protect neighbors from grazing and increase plant community diversity. Ecology 86:1856-1862.

Cantero, W.W. \& Sanford, L.L. (1984) Insect population response to mixed and uniform plantings of resistant and susceptible plant material. Environmental Entomology 13:1443-1445.

Castagneyrol, B., Giffard, B., Péré, C. \& Jactel, H. (2013) Plant apparency, an overlooked driver of associational resistance to insect herbivory. Journal of Ecology 101:418-429. 
640 Chan, E.K., Rowe, H.C. \& Kliebenstein, D.J. (2010) Understanding the evolution of

641

642

643

644

645

646

647

648

649

650

651

652

653

654

655

656

657

658

659

660

661

662

663

664

665

666

667

668

669

670

671 defense metabolites in Arabidopsis thaliana using genome-wide association mapping. Genetics 185:991-1007.

Chandra, S. \& Williams, G. (1983) Frequency-dependent selection in the grazing behaviour of the desert locust Schistocerca gregaria. Ecological Entomology 8:13-21.

Charnov, E.L. (1976) Optimal foraging, the marginal value theorem. Theoretical Population Biology 9:129-136.

Clarke, B. (1964) Frequency-dependent selection for the dominance of rare polymorphic genes. Evolution 18:364-369.

Clarke, B. (1966) The evolution of morph-ratio clines. The American Naturalist 100:389-402.

Crutsinger, G.M., Collins, M.D., Fordyce, J.A., Gompert, Z., Nice, C.C. \& Sanders, N.J. (2006) Plant genotypic diversity predicts community structure and governs an ecosystem process. Science 313:966-968.

Cottam, D.A. (1985) Frequency-dependent grazing by slugs and grasshoppers. Journal of Ecology 73:925-933.

Courant, S. \& Fortin, D. (2010) Foraging decisions of bison for rapid energy gains can explain the relative risk to neighboring plants in complex swards. Ecology 91:1841-1849.

Damgaard, C. (1998) Plant competition experiments: testing hypotheses and estimating the probability of coexistence. Ecology 79:1760-1767.

Elle, E., van Dam, N.M. \& Hare, J.D. (1999) Cost of glandular trichomes, a "resistance" character in Datura wrightii Regel (Solanaceae). Evolution 53:22-35.

Elle, E. \& Hare, J.D. (2000) No benefit of glandular trichome production in natural populations of Datura wrightii? Oecologia 123:57-65.

Emerson, S.E., Brown, J.S., Whelan, C.J. \& Schmidt, K.A. (2012) Scale-dependent neighborhood effects: shared doom and associational refuge. Oecologia 168:659-670.

Endler, J.A. (1977) Geographic Variation, Speciation, and Clines. Princeton University Press, New Jersey. 
672 Fukano, Y. \& Yahara, T. (2012) Changes in defense of an alien plant Ambrosia

673

674

675

676

677

678

679

680

681

682

683

684

685

686

687

688

689

690

691

692

693

694

695

696

697

698

699

700

701

702

703

artemisiifolia before and after the invasion of a native specialist enemy Ophraella communa. PLoS ONE 7:e49114.

Garrido, E., Llamas-Guzmán, L.P. \& Fornoni, J. (2016) The effect of frequency-dependent selection on resistance and tolerance to herbivory. Journal of Evolutionary Biology 29:483-489.

Gigord, L.D., Macnair, M.R., \& Smithson, A. (2001) Negative frequency-dependent selection maintains a dramatic flower color polymorphism in the rewardless orchid Dactylorhiza sambucina (L.) Soò. Proceedings of the National Academy of Sciences USA 98:6253-6255.

González-Teuber, M. \& Gianoli, E. (2007) Damage and shade enhance climbing and promote associational resistance in a climbing plant. Journal of Ecology 96:122-126.

Hare, J.D. \& Elle, E. (2002) Variable impact of diverse insect herbivores on dimorphic Datura wrightii. Ecology 83:2711-2720.

Hahn, P.G. \& Orrock, J.L. (2016) Neighbor palatability generates associational effects by altering herbivore foraging behavior. Ecology 97:2103-2111.

Hjältén, J., Danell, K. \& Lundberg, P. (1993) Herbivore avoidance by association: vole and hare utilization of woody plants. Oikos 68:125-131.

Hambäck, P.A., Ågren, J. \& Ericson, L. (2000) Associational resistance: insect damage to purple loosestrife reduced in thickets of sweet gale. Ecology 81:1784-1794.

Hambäck, P.A., Björkman, M., Rämert, B. \& Hopkins, R.J. (2009) Scale-dependent responses in cabbage herbivores affect attack rates in spatially heterogeneous systems. Basic and Applied Ecology 10:228-236.

Hambäck, P.A., Inouye, B.D., Andersson, P. \& Underwood, N. (2014) Effects of plant neighborhoods on plant-herbivore interactions: resource dilution and associational effects. Ecology 95:1370-1383.

Handley, R., Ekbom, B. \& Ågren, J. (2005) Variation in trichome density and resistance against a specialist insect herbivore in natural populations of Arabidopsis thaliana. Ecological Entomology 30:284-292.

Hauser, M.T., Harr, B. \& Schlötterer, C. (2001) Trichome distribution in Arabidopsis 
704

705

706

707

708

709

710

711

712

713

714

715

716

717

718

719

720

721

722

723

724

725

726

727

728

729

730

731

732

733

734

735

thaliana and its close relative Arabidopsis lyrata: molecular analysis of the candidate gene GLABROUS1. Molecular Biology and Evolution 18: $1754-1763$.

Hay, M.E. (1986) Associational plant defenses and the maintenance of species diversity: turning competitors into accomplices. The American Naturalist 128:617-641.

Holt, R.D. \& Kotler, B.P. (1987) Short-term apparent competition. The American Naturalist 130:412-430.

Hughes, M.A. (1991) The cyanogenic polymorphism in Trifolium repens L (white clover). Heredity 66:105-115.

Hughes, A.R. (2012) A neighboring plant species creates associational refuge for consumer and host. Ecology 93:1411-1420.

Hughes, A.R., Inouye, B.D., Johnson, M.T.J., Underwood, N. \& Vellend, M. (2008) Ecological consequences of genetic diversity. Ecology Letters 11:609-623.

Hülskamp, M. (2004) Plant trichomes: a model for cell differentiation. Nature Reviews Molecular Cell Biology 5:471-480.

Inouye, B.D. (2001) Response surface experimental designs for investigating interspecific competition. Ecology 82:2696-2706.

Ishida, T., Kurata, T., Okada, K. \& Wada, T. (2008) A genetic regulatory network in the development of trichomes and root hairs. Annual Review of Plant Biology 59:365-386.

Janz, N., Bergström, A. \& Johansson, J. (2005) Frequency dependence of host plant choice within and between patches: a large cage experiment. Evolutionary Ecology 19:289-302.

Johnson, M.T.J, Lajeunesse, M.J. \& Agrawal, A.A. (2006) Additive and interactive effects of plant genotypic diversity on arthropod communities and plant fitness. Ecology Letters 9:24-34.

Karban, R. (2007) Associational resistance for mule's ears with sagebrush neighbors. Plant Ecology 191:295-303.

Karban, R. \& Maron, J. (2002) The fitness consequences of interspecific eavesdropping between plants. Ecology 83:1209-1213.

Kärkkäinen, K. \& Ågren, J. (2002) Genetic basis of trichome production in Arabidopsis 
736

737

738

739

740

741

742

743

744

745

746

747

748

749

750

751

752

753

754

755

756

757

758

759

760

761

762

763

764

765

766

767

lyrata. Hereditas 136:219-226.

Kawagoe, T. \& Kudoh, H. (2010) Escape from floral herbivory by early flowering in Arabidopsis halleri subsp. gemmifera. Oecologia 164:713-720.

Kawagoe, T., Shimizu, K.K., Kakutani, T. \& Kudoh, H. (2011) Coexistence of trichome variation in a natural plant population: a combined study using ecological and candidate gene approaches. PLOS ONE 6:e22184.

Kim, T.N., Underwood, N. \& Inouye, B.D. (2013) Insect herbivores change the outcome of plant competition through both inter- and intraspecific processes. Ecology 94:1753-1763.

Kim, T.N. \& Underwood, N. (2015) Plant neighborhood effects on herbivory: damage is both density and frequency dependent. Ecology 96:1431-1437.

Kivimäki, M., Kärkkäinen, K., Gaudeul, M., Løe, G. \& Ågren, J. (2007) Gene, phenotype and function: GLABROUS1 and resistance to herbivory in natural populations of Arabidopsis lyrata. Molecular Ecology 16:453-462.

Lankau, R.A. \& Kliebenstein, D.J. (2009) Competition, herbivory and genetics interact to determine the accumulation and fitness consequences of a defence metabolite. Journal of Ecology 97:78-88.

Le Guigo, P., Rolier, A. \& Le Corff, J. (2012) Plant neighborhood influences colonization of Brassicaceae by specialist and generalist aphids. Oecologia 169:753-761.

Lefcheck, J.S., Whalen, M.A., Davenport, T.M., Stone, J.P. \& Duffy, J.E. (2013) Physiological effects of diet mixing on consumer fitness: a meta-analysis. Ecology 94:565-572.

Le Rouzic, A., Hansen, T.F., Gosden, T.P. \& Svensson, E.I. (2015) Evolutionary time-series analysis reveals the signature of frequency-dependent selection on a female mating polymorphism. The American Naturalist 185:E182-E196.

Levene, H. (1953) Genetic equilibrium when more than one ecological niche is available. The American Naturalist 87:331-333.

Løe, G., Toräng, P., Gaudeul, M., \& Ågren, J. (2007) Trichome production and spatiotemporal variation in herbivory in the perennial herb Arabidopsis lyrata. Oikos 116:134-142. 
768 Mauricio, R. (1998) Costs of resistance to natural enemies in field populations of the

769

770

771

772

773

774

775

776

777

778

779

780

781

782

783

784

785

786

787

788

789

790

791

792

793

794

795

796

797

798

799 annual plant Arabidopsis thaliana. The American Naturalist 151:20-28.

Miller, A.M., McArthur, C. \& Smethurst, P.J. (2009) Spatial scale and opportunities for choice influence browsing and associational refuges of focal plants. Journal of Animal Ecology 78:1134-1142.

Miller, T.E. \& Rudgers, J.A. (2014) Niche differentiation in the dynamics of host-symbiont interactions: symbiont prevalence as a coexistence problem. The American Naturalist 183:506-518.

Oppenheimer, D.G., Herman, P.L., Sivakumaran, S., Esch, J. \& Marks, M.D. (1991) A myb gene required for leaf trichome differentiation in Arabidopsis is expressed in stipules. Cell 67:483-493.

Parker, J.D., Salminen, J. \& Agrawal, A.A. (2010) Herbivory enhances positive effects of plant genotypic diversity. Ecology Letters 13:553-563.

Rand, T.A. (2003) Herbivore-mediated apparent competition between two salt marsh forbs. Ecology 84:1517-1526.

Rausher, M.D. (1981) The effect of native vegetation on the susceptibility of Aristolochia reticulata (Aristolochiaceae) to herbivore attack. Ecology 62:1187-1195.

Rautio, P., Bergvall, U.A., Tuomi, J., Kesti, K. \& Leimar, O. (2012) Food selection by herbivores and neighbourhood effects in the evolution of plant defences. Annales Zoologici Fennici 49:45-57.

Rhoades, D.F. (1979) Evolution of plant chemical defense against herbivores. In: Rosenthal, G.A. \& Janzen, D.H. (eds). Herbivores: Their Interaction with Secondary Plant Metabolites. Academic Press, New York, pp. 2-54.

Risch, S.J. (1981) Insect herbivore abundance in tropical monocultures and polycultures: an experimental test of two hypotheses. Ecology 62:1325-1340.

Root, R.B. (1973) Organization of a plant-arthropod association in simple and diverse habitats: the fauna of Collards (Brassica oleracea). Ecological Monographs 43:95-124.

Russell, F.L. \& Louda, S.M. (2004) Phenological synchrony affects interaction strength of an exotic weevil with Platte thistle, a native host plant. Oecologia 
800

801

802

803

804

805

806

807

808

809

810

811

812

813

814

815

816

817

818

819

820

821

822

823

824

825

826

827

828

829

830

831

139:525-534.

Russell, F.L. \& Louda, S.M. (2005) Indirect interaction between two native thistles mediated by an invasive exotic floral herbivore. Oecologia 146:373-384.

Sabelis, M.W. \& de Jong, M.C. (1988) Should all plants recruit bodyguards? Conditions for a polymorphic ESS of synomone production in plants. Oikos 53:247-252.

Sakata, Y., Yamasaki, M., Isagi, Y. \& Ohgushi, T. (2014) An exotic herbivorous insect drives the evolution of resistance in the exotic perennial herb Solidago altissima. Ecology 95:2569-2578.

Sato, Y. (2016) Associational anti-herbivore defense in the trichome dimorphism of Arabidopsis halleri subsp. gemmifera (Brassicaceae). Ph.D. Thesis, Kyoto University.

Sato, Y., Kawagoe, T., Sawada, Y., Hirai, M.Y. \& Kudoh, H. (2014) Frequency-dependent herbivory by a leaf beetle, Phaedon brassicae, on hairy and glabrous plants of Arabidopsis halleri subsp. gemmifera. Evolutionary Ecology 28:545-559.

Sato, Y. \& Kudoh, H. (2015) Tests of associational defence provided by hairy plants for glabrous plants of Arabidopsis halleri subsp. gemmifera against insect herbivores. Ecological Entomology 40:269-279.

Sato, Y. \& Kudoh, H. (2016a) Presence of substitute diets alters plant resistance to specialist and generalist herbivores: a meta-analysis. Ecosphere 7:e01446.

Sato, Y. \& Kudoh, H. (2016b) Associational effects against a leaf beetle mediate a minority advantage in defense and growth between hairy and glabrous plants. Evolutionary Ecology 30:137-154.

Sato, Y. \& Kudoh, H. (2017a) Fine-scale frequency differentiation along a herbivory gradient in the trichome dimorphism of a wild Arabidopsis. Ecology and Evolution 7:2133-2141.

Sato, Y. \& Kudoh, H. (2017b) Herbivore-mediated interaction promotes the maintenance of trichome dimorphism through negative frequency-dependent selection. The American Naturalist 190:E67-E77.

Sato, Y., Ito, K. \& Kudoh, H. (2017) Optimal foraging by herbivores maintains polymorphism in defence in a natural plant population. Functional Ecology 
31:2233-2243.

833 Schoonhoven, L.M., van Loon, J.J.A. \& Dicke, M. (2005) Insect-Plant Biology (2 ${ }^{\text {nd }}$ edn). Oxford University Press, Oxford.

Sholes, O.D.V. (2008) Effects of associational resistance and host density on woodland insect herbivores. Journal of Animal Ecology 77:16-23.

Simms, E.L. (1992) Costs of plant resistance to herbivory. In: Fritz, R.S., Simms, E.L. (eds). Plant Resistance to Herbivores and Pathogens: Ecology, Evolution, and Genetics. University of Chicago Press, Chicago, pp. 392-425.

Sletvold, N., Huttunen, P., Handley, R., Kärkkäinen, K. \& Ågren, J. (2010) Cost of trichome production and resistance to a specialist insect herbivore in Arabidopsis lyrata. Evolutionary Ecology 24:1307-1319.

Spichtig, M. \& Kawecki, T. (2004) The maintenance (or not) of polygenic variation by soft selection in heterogeneous environments. The American Naturalist 164:70-84.

Stamp, N. (2003) Out of the quagmire of plant defense hypotheses. Quarterly Review of Biology 78:23-55.

Stastny, M. \& Agrawal, A.A. (2014) Love thy neighbour? Reciprocal impacts between plant community structure and insect herbivory in co-occurring Asteraceae. Ecology 95:2904-2914.

Tahvanainen, J.O. \& Root, R.B. (1972) The influence of vegetational diversity on the population ecology of a specialized herbivore, Phyllotreta cruciferae (Coleoptera: Chrysomelidae). Oecologia 10:321-346.

Thompson, J.N. (2005) The Geographic Mosaic of Coevolution. University of Chicago Press, Chicago.

Tuomi, J., Augner, M. \& Leimar, O. (1999) Fitness interactions among plants: optimal

Till-Bottraud, I. \& Gouyon, P.H. (1992) Intra-versus interplant Batesian mimicry? A model on cyanogenesis and herbivory in clonal plants. The American Naturalist 139:509-520. defence and evolutionary game theory. In: Vuorisalo, T.O. \& Mutikaine, P.K. (eds). Life-history Evolution in Plants. Kluwer Academic Publishers,

863 Turcotte, M.M., Reznick, D.N. \& Hare, J.D. (2011) The impact of rapid evolution on 
864

865

866

867

868

869

870

871

872

873

874

875

876

877

878

879

880

881

882

883

884

885

886

887

888

889

890

891

892

893

894

895

population dynamics in the wild: experimental test of eco-evolutionary dynamics. Ecology Letters 14:1084-1092.

Turcotte, M.M., Reznick, D.N. \& Hare, J. D. (2013) Experimental test of an eco-evolutionary dynamic feedback loop between evolution and population density in the green peach aphid. The American Naturalist 181:S46-S57.

Turelli, M., Schemske, D.W. \& Bierzychudek, P. (2001) Stable two-allele polymorphisms maintained by fluctuating fitnesses and seed banks: protecting the blues in Linanthus parryae. Evolution 55:1283-1298.

Toju, H., Ueno, S., Taniguchi, F. \& Sota, T. (2011) Metapopulation structure of a seed-predator weevil and its host plant in arms race coevolution. Evolution 65:1707-1722.

Underwood, N., Inouye, B.D. \& Hambäck, P.A. (2014) A conceptual framework for associational effects: when do neighbors matter and how would we know? Quarterly Review of Biology 89:1-19.

van Dam, N.M., Hare, J.D. \& Elle, E. (1999) Inheritance and distribution of trichome phenotypes in Datura wrightii. Journal of Heredity 90:220-227.

Verschut, T.A., Becher, P.G., Anderson, P. \& Hambäck, P.A. (2016) Disentangling associational effects: both resource density and resource frequency affect search behaviour in complex environments. Functional Ecology 30:1826-1833.

Wahl, M. \& Hay, M.E. (1995) Associational resistance and shared doom: effects of epibiosis on herbivory. Oecologia 102:329-340.

Wetzel, W.C., Kharouba, H.M., Robinson, M., Holyoak, M. \& Karban, R. (2016) Variability in plant nutrients reduces insect herbivore performance. Nature 539:425-427.

Wise, M.J. (2009) To duck or not to duck: resistance advantages and disadvantages of the candy-cane stem phenotype in tall goldenrod, Solidago altissima. New Phytologist 183:900-907.

Wise, M.J., Yi, C.G. \& Abrahamson, W.G. (2009) Associational resistance, gall-fly preferences, and a stem dimorphism in Solidago altissima. Acta Oecologica 35:471-476.

White, J.A. \& Whitham, T.G. (2000) Associational susceptibility of cottonwood to a box 
elder herbivore. Ecology 81:1795-1803.

897

898

899

900

901

902

903

904

905

906

907

908

909

910

911

Zakir, A., Sadek, M.M., Bengtsson, M., Hansson, B.S., Witzgall, P., Anderson, P. (2013) Herbivore-induced plant volatiles provide associational resistance against an ovipositing herbivore. Journal of Ecology 101:410-417.

Zangerl, A.R. \& Berenbaum, M.R. (2003) Phenotype matching in wild parsnip and parsnip webworms: causes and consequences. Evolution 57:806-815.

Zangerl, A.R., Stanley, M.C. \& Berenbaum, M.R. (2008) Selection for chemical trait remixing in an invasive weed after reassociation with a coevolved specialist. Proceedings of the National Academy of Sciences USA 105:4547-4552.

Züst, T., Joseph, B., Shimizu, K.K., Kliebenstein, D.J. \& Turnbull, L.A. (2011) Using knockout mutants to reveal the growth costs of defensive traits. Proceedings of the Royal Society of London B: Biological Sciences 278:2598-2603.

Züst, T., Heichinger, C., Grossniklaus, U., Harrington, R., Kliebenstein, D.J., \& Turnbull, L.A. (2012) Natural enemies drive geographic variation in plant defenses. Science 338:116-119. 
912 Table 1. Examples of associational effects that cause frequency- and/or density-dependent herbivory between plant species/genotypes.

\begin{tabular}{|c|c|c|c|c|}
\hline \multirow[t]{2}{*}{ Factor } & \multirow[t]{2}{*}{ Article } & \multicolumn{2}{|c|}{ Study system } & \multirow[t]{2}{*}{ Neighborhood composition } \\
\hline & & Plant (or Resource) & Herbivore (or Consumer) & \\
\hline \multirow[t]{2}{*}{ Density } & Rand (2003) & $\begin{array}{l}\text { Atriplex patula and Salicornia } \\
\text { europaea }\end{array}$ & $\begin{array}{l}\text { Polyphagous beetle Erynephala } \\
\text { maritima }\end{array}$ & $\begin{array}{l}\text { Presence/absence of the other species } \\
\text { with low/high density }\end{array}$ \\
\hline & Russell \& Louda (2005) & Cirsium canescens and $C$. undulatum & $\begin{array}{l}\text { Florivorous weevil Rhinocyllus } \\
\text { conicus }\end{array}$ & $\begin{array}{l}\text { Density of the other species in natural } \\
\text { populations }\end{array}$ \\
\hline \multirow[t]{4}{*}{ Frequency } & Bergvall et al. (2006) & Low- and high-tannin food & Fallow deer Dama dama & $\begin{array}{l}\text { Rare or abundant type A against B (= } 2 \\
\text { frequency conditions) }\end{array}$ \\
\hline & Wise et al. (2009) & $\begin{array}{l}\text { Candy-cane and erect-stem genotype of } \\
\text { Solidago altissima }\end{array}$ & $\begin{array}{l}\text { Oligophagous gall-fly Eurosta } \\
\text { solidaginis }\end{array}$ & $\begin{array}{l}\text { Rare or abundant type A against B (= } \\
\text { frequency conditions) }\end{array}$ \\
\hline & Sato \& Kudoh (2016b) & $\begin{array}{l}\text { Hairy and glabrous genotype of } \\
\text { Arabidopsis halleri subsp. gemmifera }\end{array}$ & $\begin{array}{l}\text { Oligophagous beetle Phaedon } \\
\text { brassicae }\end{array}$ & $\begin{array}{l}\text { Rare or abundant type A against B (= } \\
\text { frequency conditions) }\end{array}$ \\
\hline & Garrido et al. (2016) & $\begin{array}{l}\text { Resistant and tolerent genotype of } \\
\text { Datura stramonium }\end{array}$ & $\begin{array}{l}\text { Oligophagous beetle Lema } \\
\text { daturaphila }\end{array}$ & $\begin{array}{l}\text { Rare, even, and abundant type A agains } \\
\text { type B (= } 3 \text { frequency conditions) }\end{array}$ \\
\hline \multirow[t]{3}{*}{ Both } & Kim \& Underwood (2015) & $\begin{array}{l}\text { Solidago altissima and Solanum } \\
\text { carolinense }\end{array}$ & (incl. multiple species) & $\begin{array}{l}\text { Response surface design of } 4 \text { frequency } \\
\text { and } 4 \text { density conditions }\end{array}$ \\
\hline & Hahn \& Orrock (2016) & Solidago nemoralis and S. odora & Grasshoppers & $\begin{array}{l}\text { Rare, even, and abundant type A agains } \\
\text { type B (= } 3 \text { frequency conditions) at } \\
\text { high/low densities. }\end{array}$ \\
\hline & Verschut et al. (2016) & Balsamic vinegar solutions & Drosophila melanogaster & $\begin{array}{l}\text { Different resource concentration ( } 2 \\
\text { levels) with } 3 \text { or } 5 \text { frequency conditions }\end{array}$ \\
\hline
\end{tabular}




\section{$914 \quad$ Figure legends}

915 Figure 1. Stepwise approach to reveal causes and consequences of associational effects

916 (AE) on plant coexistence. The reference indicates studies comprising a focal approach.

917 Details of the selected references are shown in Appendix.

918

919 Figure 2. Comprehensive test for the maintenance of the trichome dimorphism of

920 Arabidopsis halleri subsp. gemmifera mediated by associational effects against a leaf

921 beetle Phaedon brassicae. (a) Photographs of plants and insects; (b) Empirical

922 approaches from laboratory experiments to field observation; (c) Modeling herbivory,

923 plant fitness, and polymorphism dynamics. Insets in the panel (c) are modified from

924 Sato et al. (2017).

925

926 Figure 3. Mechanism through which associational effects and a cost of defense jointly

927 cause negative frequency-dependent selection between hairy and glabrous plants. Panels

928 (a), (b) and (c) represent differences in herbivory, intrinsic fitness, and realized fitness

929 between hair and glabrous plants, respectively. $\mathrm{H}>\mathrm{G}$ and $\mathrm{H}<\mathrm{G}$ indicates

930 hairy-abundant and glabrous-abundant condition, respectively.

931

932 Figure 4. Evolutionary dynamics wherein the trichome dimorphism of Arabidopsis

933 halleri subsp. gemmifera can be maintained by the herbivore-mediated

934 frequency-dependent selection. Frequency-dependent feeding preference by herbivores

935 and plant defense-growth tradeoff results in a negative feedback loop that allows rarer

936 plant morphs to invade into a population.

937

938 Figure 5. Specific hypothesis for how local-scale associational effects (AE) contribute

939 to geographic variation in plant defense via the maintenance of source population in a

940 polymorphism. (a) Relationship between the herbivory pressure and morph-frequency

941 in the presence (solid line) and absence (dashed line) of AE. (b) Contribution of a

942 source polymorphic population created by AE to the maintenance of polymorphism at a

943 metapopulation scale. Grey and white square represents the region of intense and

944 moderate herbivory, respectively. White arrows represent gene flow from a source to

945 nearby populations. 


\section{$946 \quad$ Figure 1}

\section{Mechanism}

Approach 1: Identifying herbivore behaviors and plant traits

- Behavioral assay for herbivores ${ }^{[1,2,3]}$

- Measurement of key plant traits ${ }^{[3,4,5,8]}$

Approach 2: Manipulative experiments demonstrating AE

Manipulating

- Neighborhood composition in plants

- Presence/absence of herbivores ${ }^{[5,6,7]}$

\section{Approach 3: Field pattern of herbivory and plant population dynamics}

Multi-year field census on

- Patterns of the damage and herbivore abundance on plants ${ }^{[1,8]}$

- Plant fitness ${ }^{[5,9]}$ and population growth ${ }^{[7]}$

\section{Pattern}

[1] Tahvanainen \& Root (1972); [2] White \& Whitham (2000); [3] Bergvall et al. (2006); [4] Barton \& Browers (2006);

[5] Agrawal (2004); [6] Rand (2003); [7] Callaway et al. (2005); [8] Russell \& Louda (2005); [9] Karban \& Maron (2002)

948

949

950

951

952

953

954

955

956

957

958

959

960 
$961 \quad$ Figure 2

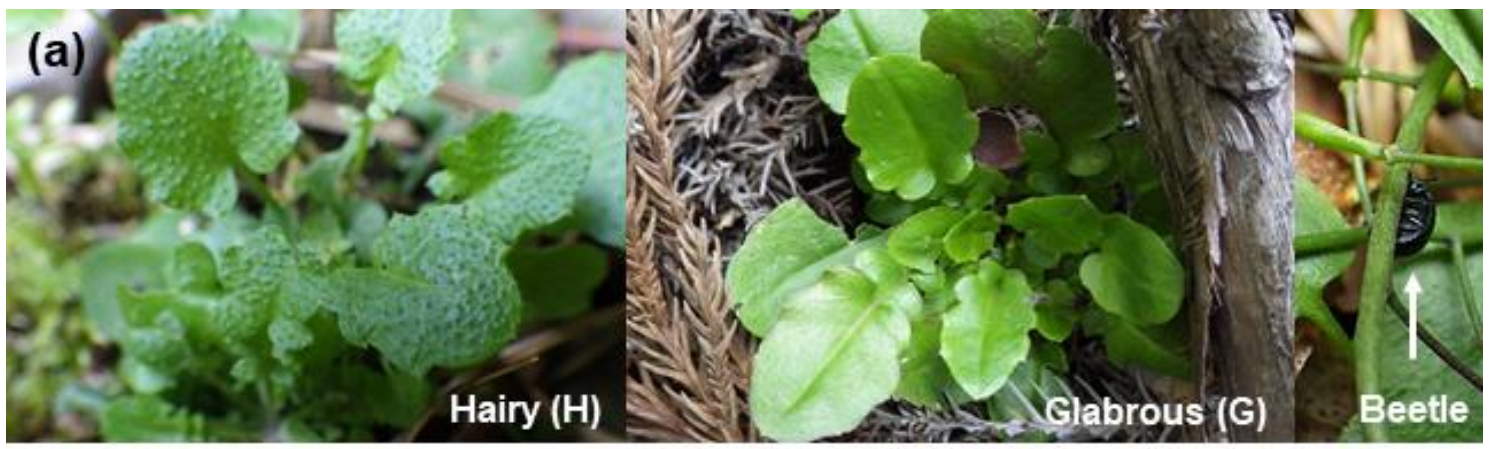

(b) Approach 1:

Approach 2:

Approach 3:

(b) Behavioral assay

Manipulative experiment

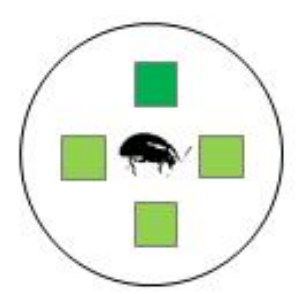

\begin{tabular}{|l|c|c|}
\hline & Beetle+ & Beetle- \\
\hline H> G & \\
\hline H<G & \\
\hline
\end{tabular}

Field observation

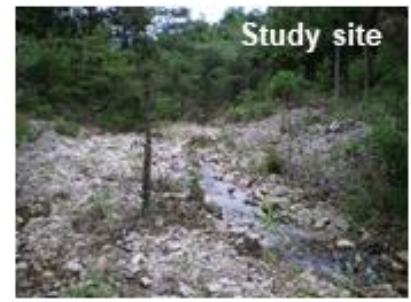

\section{Data + Modeling}
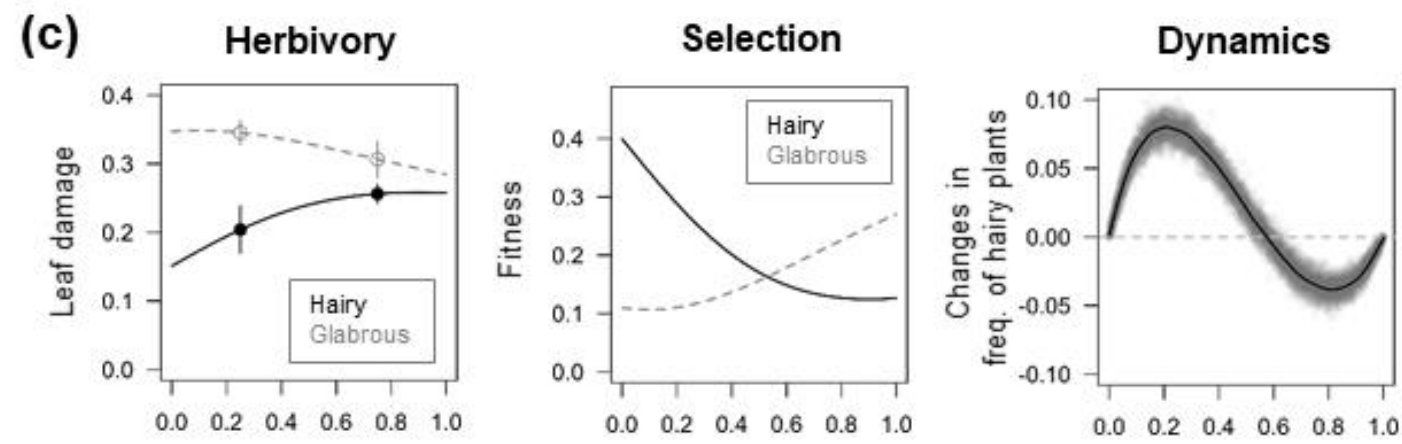

Frequency of hairy plants 
968 Figure 3

(a)

(a) Beetle-present condition

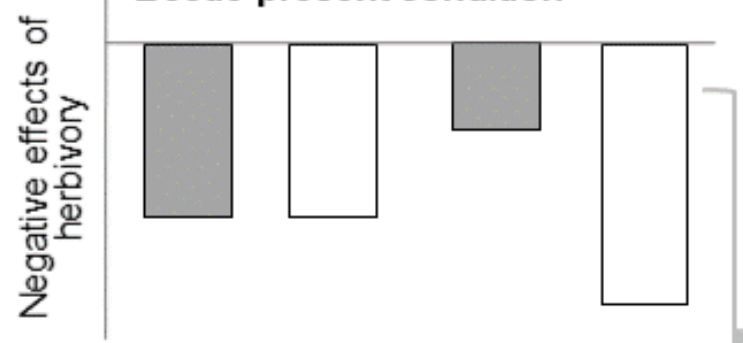

(b) Beetle-absent condition

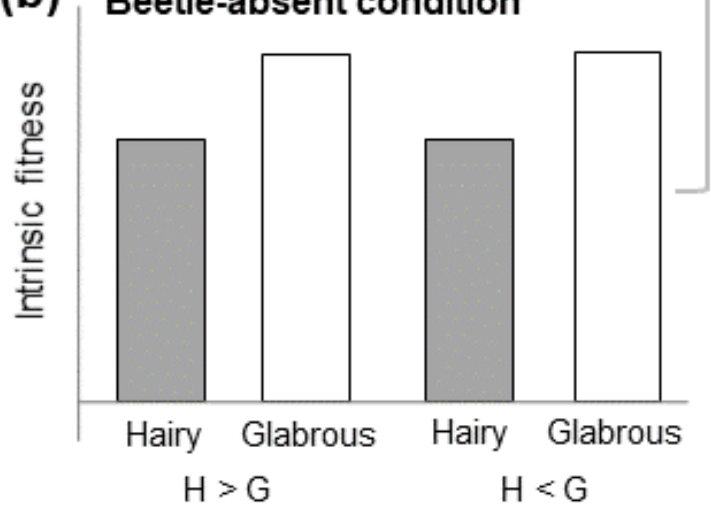

(c) Beetle-present condition

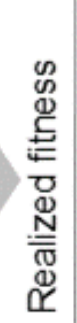

969

970

971

972

973

974

975

976

977

978

979

980

981 
$982 \quad$ Figure 4

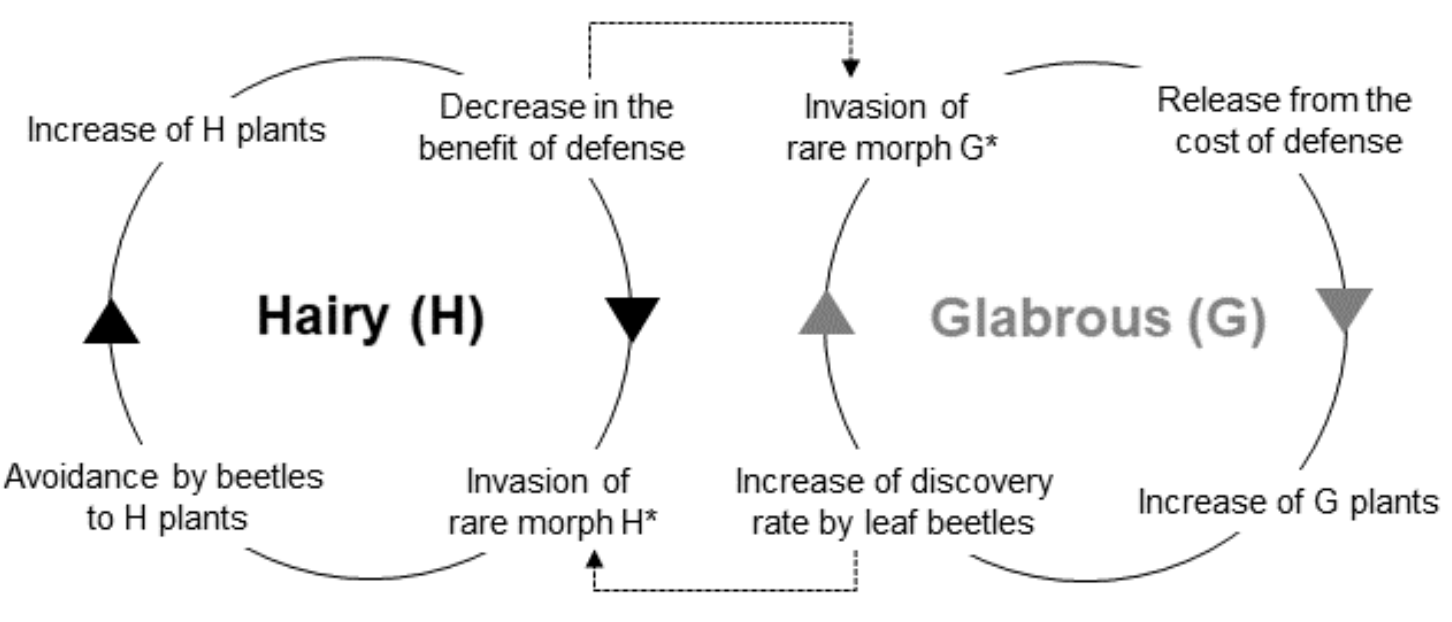

984

985

986

987

988

989

990

991

992

993

994

995

996

997

998

999 
$1000 \quad$ Figure 5

(a)

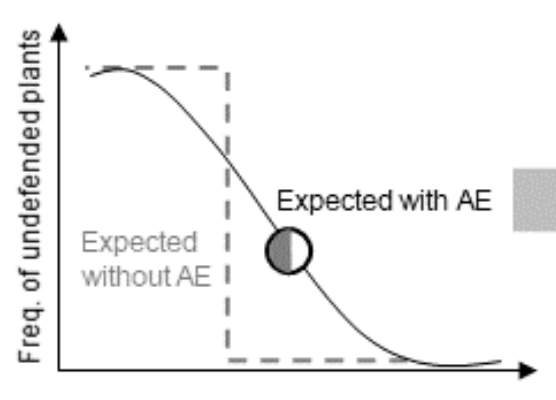

Herbivory pressure (b)

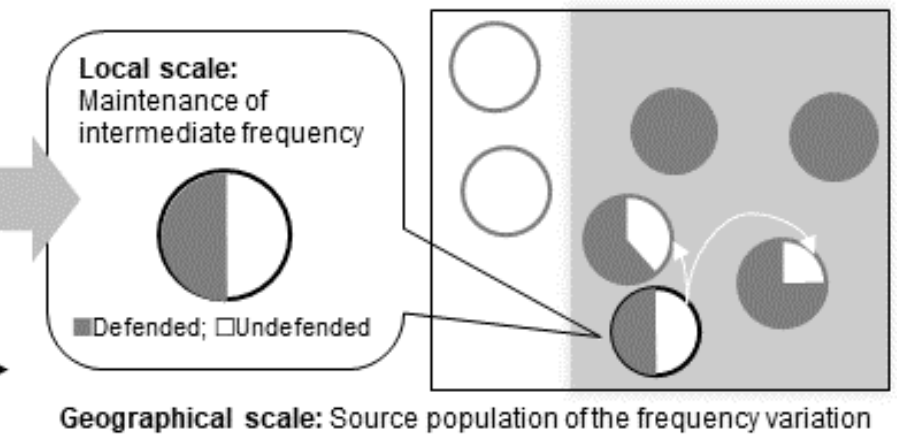

1002

1003

1004

1005

1006

1007

1008

1009

1010

1011

1012

1013

1014

1015

1016

1017

1018 


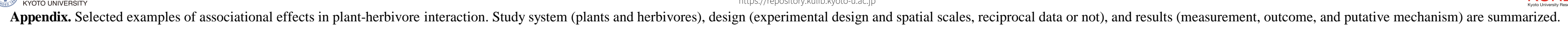

\begin{tabular}{|c|c|c|c|c|c|c|c|c|c|}
\hline \multirow[t]{2}{*}{ Reference } & \multicolumn{3}{|c|}{ Study system } & \multicolumn{3}{|l|}{ Study design } & \multicolumn{3}{|c|}{ Results } \\
\hline & Herbivore & Plant species & Plant traits & Experimental design & Scale & Reciprocal or not & Measurement & Outcome & Mechanism \\
\hline $\begin{array}{l}\text { Tahvanainen \& Root } \\
\text { (1972) }\end{array}$ & $\begin{array}{l}\text { A specialist flea } \\
\text { beetle (Phyllotreta } \\
\text { cruciferae) }\end{array}$ & $\begin{array}{l}\text { Brassica oleracea and } \\
\text { tomato or tobacco }\end{array}$ & $\begin{array}{l}\text { Odor (shown by a } \\
\text { choice assay) }\end{array}$ & $\begin{array}{l}\text { Monoculture of } B \text {. oleracea and polyculture of three species. } \\
\text { The tomato and tobacco was added to the equal density of } B \text {. } \\
\text { oleracea in the polyculture. }\end{array}$ & Within-patch & $\begin{array}{l}\text { NA for tomato and } \\
\text { tobacco }\end{array}$ & $\begin{array}{l}\text { The number of } \\
\text { beetles per plant and } \\
\text { plant biomass for } B \text {. } \\
\text { oleracea }\end{array}$ & $\begin{array}{l}\text { AR: The number of beetles per plant was } \\
\text { higher, and plant biomass decreased } \\
\text { under the monoculture. }\end{array}$ & $\begin{array}{l}\text { Odor cues for } \\
\text { herbivores }\end{array}$ \\
\hline Rausher (1981) & $\begin{array}{l}\text { A specialist butterfly } \\
\text { (Battus philenor) }\end{array}$ & $\begin{array}{l}\text { Aristolochia reticulata } \\
\text { and others species in } \\
\text { near vegetation }\end{array}$ & Unidentified & $\begin{array}{l}0.5 \mathrm{~m} \text {-radius vegetation surrounding an } A . \text { reticulata } \\
\text { individual was removed. Non-removed patches were assigned } \\
\text { to the control. }\end{array}$ & Within-patch & $\begin{array}{l}\text { NA for } \\
\text { counterparts }\end{array}$ & $\begin{array}{l}\text { Oviposition per } A \text {. } \\
\text { reticulata plant }\end{array}$ & $\begin{array}{l}\text { AR: Isolated plants suffer more } \\
\text { oviposition, butterflies spend more time } \\
\text { in the isolated patch. }\end{array}$ & $\begin{array}{l}\text { Searching } \\
\text { effeciency of } \\
\text { herbivores }\end{array}$ \\
\hline Risch (1981) & $\begin{array}{l}\text { Mono- Oligo-, } \\
\text { Polyphagous beetles } \\
\text { (6 species) }\end{array}$ & $\begin{array}{l}\text { Corn (Zea mays), } \\
\text { beans (Phaseolus } \\
\text { vulgaris }), \text { and squash } \\
(\text { Cucurbita maxima })\end{array}$ & Unidentified & $\begin{array}{l}\text { Intercropping one crops into another; monoculture, diculture } \\
\text { triculture for } 3 \text { species ( } 7 \text { conditions) }\end{array}$ & Within-patch & Reciprocal & $\begin{array}{l}\text { No of beetles per } \\
\text { plant }\end{array}$ & $\begin{array}{l}\text { AR: The beetle abundance reduced under } \\
\text { polycultic conditions except for a squash- } \\
\text { bean diculture }\end{array}$ & $\begin{array}{l}\text { Resource } \\
\text { concentration (plant } \\
\text { density) }\end{array}$ \\
\hline Hay (1986) & Generalist fishes & $\begin{array}{l}\text { Multiple species of } \\
\text { Marine algae }\end{array}$ & Unidentified & Solitary or paired culture in a closed cage & Within-patch & Reciprocal & $\begin{array}{l}\text { Within-patch: } \\
\text { predation risk by } \\
\text { fishes }\end{array}$ & $\begin{array}{l}\text { AR for palatable algae to generalist } \\
\text { fishes }\end{array}$ & $\begin{array}{l}\text { Physical } \\
\text { attachments to } \\
\text { unpalatable algae }\end{array}$ \\
\hline White \& Whitham (2000) & $\begin{array}{l}\text { Fall cankerworm } \\
\text { (Alsophila } \\
\text { pometaria). }\end{array}$ & $\begin{array}{l}\text { Cotton (Populus } \\
\text { angustifolia } \times P \text {. } \\
\text { fremontii), and box } \\
\text { elder (Acer negundo })\end{array}$ & $\begin{array}{l}\text { Unknown, (but a } \\
\text { choice test showed } \\
\text { that the } \\
\text { cankerworm prefer } \\
\text { to the box elder). }\end{array}$ & $\begin{array}{l}\text { Transplanting juvenile cottons to three conditions: Nearby box } \\
\text { elder, Nearby matured cotton, Stand alone. }\end{array}$ & Within-patch & $\begin{array}{l}\text { NA for the box } \\
\text { elder }\end{array}$ & $\begin{array}{l}\text { Larvae density per } \\
\text { shoot of the juvenile } \\
\text { cotton }\end{array}$ & $\begin{array}{l}\text { AS: Cotton suffered from the higher } \\
\text { density nearby a heterospecific } \\
\text { counterpart than nearby conspecifics or } \\
\text { stand alone. }\end{array}$ & $\begin{array}{l}\text { Herbivore dispersal } \\
\text { from palatable to } \\
\text { unpalatable plants }\end{array}$ \\
\hline Karban \& Maron (2002) & $\begin{array}{l}\text { Generalist grass- } \\
\text { hoppers (incl. } \\
\text { multiple species) }\end{array}$ & $\begin{array}{l}\text { Sagebrush (Artemisia } \\
\text { tridentata) and } \\
\text { tobacco (Nicotiana } \\
\text { attenuata })\end{array}$ & Volatile chemical & Tobacco was transferred near damaged or intact sagebrush. & Within-patch & NA for Sagebrush & $\begin{array}{l}\text { The number of } \\
\text { flowers and capsules } \\
\text { per tobacco }\end{array}$ & $\begin{array}{l}\text { AR: tobacco produced more flowers and } \\
\text { capsules nearby damaged sagebrush. }\end{array}$ & $\begin{array}{l}\text { Volatile } \\
\text { communication } \\
\text { between plants }\end{array}$ \\
\hline Hambäck et al. (2000) & $\begin{array}{l}\text { A specialist leaf } \\
\text { beetle (Galerucella } \\
\text { calmariensis) }\end{array}$ & $\begin{array}{l}\text { An aromatic shrub } \\
\text { (Myrica gale) and a } \\
\text { perrenial herb } \\
\text { (Lythrum salicaria) }\end{array}$ & Unidentified & Stand-alone or within- $M$. gale patch condition for $L$. salicaria & Within-patch & NA for M. gale & $\begin{array}{l}\text { Oviposition, leaf } \\
\text { damage, seed } \\
\text { production per } \\
\text { individual } L \text {. } \\
\text { salicaria. }\end{array}$ & $\begin{array}{l}\text { AR: L. salicaria incurred less oviposition } \\
\text { and damage, and produce more seeds } \\
\text { nearby } M \text {. gale }\end{array}$ & $\begin{array}{l}\text { Odor or vidual } \\
\text { cypsis. Predator } \\
\text { abundance did not } \\
\text { differ between the } \\
\text { two conditions. }\end{array}$ \\
\hline Rand (2003) & $\begin{array}{l}\text { A generalist leaf } \\
\text { beetle (Erynephalam } \\
\text { aritima) }\end{array}$ & $\begin{array}{l}\text { Two forbs, Atriplex } \\
\text { patula var. hastata } \\
\text { and Salicorniae } \\
\text { uropaea }\end{array}$ & $\begin{array}{l}\text { Unidentified (but } \\
\text { feeding preference } \\
\text { was shown by a } \\
\text { choice test). }\end{array}$ & $\begin{array}{l}\text { The presence/absence of herbivores for } 3 \text { conditions: Atriplex } \\
\text { alone with low density, Atriplex alone with high density, } \\
\text { Atriplex with Salicornia }\end{array}$ & Within-patch & NA for Salicornia & $\begin{array}{l}\text { Leaf damage, the } \\
\text { number of larvae, and } \\
\text { survival (\%) of plants. }\end{array}$ & $\begin{array}{l}\text { AS: Atriplex suffered more leaf damage } \\
\text { and less survival nearby Salicornia }\end{array}$ & $\begin{array}{l}\text { Diet-mixing by } \\
\text { generalist herbivore }\end{array}$ \\
\hline Agrawal (2004) & $\begin{array}{l}\text { A specialist beetle } \\
\text { (Tetraopes } \\
\text { tetraophthalmus) }\end{array}$ & $\begin{array}{l}\text { a milkweed (Asclepias } \\
\text { syriaca) and a grass } \\
\text { (Liriomyza } \\
\text { asclepiadis) }\end{array}$ & $\begin{array}{l}\text { Trichome, Latex, } \\
\text { Nitrogen contents }\end{array}$ & $\begin{array}{l}\text { Grasses or beetles were added to a potted milkweed: } 4 \\
\text { treatments of Control, Grass+, Beetle+, and Grass\&Beetle+. } \\
\text { Grass alone, Grass\&Milk\&Beetle, Grass\&Milk was also set. }\end{array}$ & Within-patch & $\begin{array}{l}\text { Grass biomass } \\
\text { data: Grass alone }= \\
\text { Grass\&Milk\&Beet } \\
\text { le }>\text { Grass\&Milk }\end{array}$ & $\begin{array}{l}\text { Milkweed biomass, } \\
=\text { fruit production, fruit } \\
\text { mass; and grass } \\
\text { biomass }\end{array}$ & $\begin{array}{l}\text { AS: milkweed biomass and fecundity was } \\
\text { Control } \fallingdotseq \text { Grass }+>\text { Beetle }+> \\
\text { Grass\&Beetle+. }\end{array}$ & $\begin{array}{l}\text { Dispersal from } \\
\text { primary host plants } \\
\text { to secondary ones. }\end{array}$ \\
\hline
\end{tabular}


Cirsium) or toxin Four focal species $\times$ within/outside grazing fence $\times$ exclusion herbs (Anthoxanthum, (for Veratrum)

of Cirsium or Veratrum $=24$ treatments Phleum )

\section{Two congeneric}

Florivorous weevil, natives, Cirsium

Rhinocyllus conicus canescens and $C$.

undulatum

Plant phenology $>10$-yrs field census in 13 sites where the two plant species co-occur

and-patch and good-patch contains 7:1 and 1:7 of high:low

Unknown. Synthetic ood containing different tannin levels Chemical (Tannin) tannin buckets, respectively. Single- and group-foraging of deers were also tested.

Within an

dama)

Interspecific: two

None (only defense congeners, Plantago lanceolata and $P$ major

Chemical (Iridoid 2 species $\times$ (conspecific, heterospecific, no neighbor) $\times 2$ evaluated)

\section{A specialist aphid $\quad$ Three Brassica
(Brevicoryne \\ (Brevicoryne}

Le Guigo et al. (2012) brassicae) an

generalist aphid

species and

(Myzus persicae) lycopersicum)

Leaf-chewers

Betula pendula

(beetles, caterpillars, Quercus robur

Castagneyrol et al. (2013) and grasshoppers) or Quercus pyrenaica,

Leaf-miners (incl. 5 Quercus ilex, Pinus

species)

pinaster

glucoside)

harvesting time points $=12$ conditions

ithin-patch Reciproca

Chemical

(glucosinolate?)

A Brassicae oleracea individual was surrounded by 6

conspecific or heterospecific individuals $(=7$ treatments in

total)

Plant height, and

Leaf area loss (by
Relative values of chewers)

two species (for miner abundance at

een patch plant height data)

Response surface design $(1,6,12,18$ total plant number with specialists (for $S$

Kim \& Underwood (2015) cacolinense) S. Solanum carolinense, carolinense), and $3 \quad$ Solidago altissima

Unidentified

Response surface design $(1,6$ miner abundance at scale

AR: increased growth rate of two

palatable species, no increase of growth avoidance by

Cirsium and Veratrum

$\begin{array}{lll}\text { Proportion of weevils } & \text { AR for } C \text {. undulatum: The proportion of } & \text { Phenological } \\ \text { weevils and eggs was negatively } & \text { syncronicity of }\end{array}$

and their eggs on $C$. correlated with the number of $C$ flowering between

canescens.

the two species.

AS for low-tannin buckets: More

consumption on low-tannin buckets in

Log-consumption per the bad-patch than those in the good-

patch. AR for high-tannin buckets: Less $\begin{aligned} & \text { behavior of } \\ & \text { mammalian }\end{aligned}$

within- and among-

patch foraging

patch foraging
behavior of

consumption on high-tannin buckets in herbivores

AS for $P$. lanceolata ?. P. lanceolata

Within-patch: \% Dry surrounded by heterospecific plants

Weight of Iridoid

surrounded by heterospecific plants
produced less defensive chemicals

Phat trait change

via direct

competition compared to those surrounded by

between plants.

The number of aphids

on a focal $B$.

oleracea compared AS when a herbivore is specialist; AR

between conspecific when a herbivore is generalist.

Chemical attraction

or repulsion

AR against leaf-miners: no AR against leaf-chewers

Variation in leaf

traits and apparency

(plant height)

Unknown (but

the plant density 